\title{
Perancangan Enterprise Arsitektur Menggunakan Framework Togaf
}

\author{
Studi Kasus PT. Ikido Jorr Sepatu Indo
}

\author{
Ricky Anderson ${ }^{1}$, Johanes Fernandes Andry ${ }^{2}$ \\ ${ }^{1,2}$ Sistem Informasi, Fakultas Teknologi dan Desain, Universitas Bunda Mulia, Jakarta, Indonesia \\ 1 andersonricky52.ra@gmail.com \\ 2jandry@bundamulia.ac.id
}

Diterima 03 November 2020

Disetujui 13 April 2021

\begin{abstract}
Implementation of IS / IT (Information Systems) / (Information Technology) is indispensable in a business process when a organizations wants to grow bigger, and its operational level is getting less simple, so instructions on data, technology, and application functionality will also be increasingly needed. PT Ikido Jorr Indo Sepatu is a manufacturing company that produces shoes for babies, and toddlers. The authors find problem such as most of its business processes still do not take full advantage and not optimally using IS and IT, and sometimes problems in the form of human errors, such as writing wrong memos, wrong data entry, and not having "real time" data processing between each of company division that can interfere with ongoing business processes. Therefore the authors will design a company enterprise architecture (EA) that results in harmony between IS / IT and the business needs of PT Ikido Jorr Indo Sepatu. In this study, the authors will design the EA using TOGAF (The Open Group Architecture Framework) with the ADM (Architecture Development Method) method. The results of this study are in the form of a enterprise architecture blueprint for the TOGAF method that is adapted to the business processes that are running at PT. Ikido Jorr Indo Sepatu which can help maximize the company's growth.
\end{abstract}

Index Terms-enterprise architecture; TOGAF ADM; PT Ikido Jorr Indo Sepatu

\section{PENDAHULUAN}

Sekarang IS dan teknologi adalah sangat mutlak dibutuhkan untuk kemajuan sebuah industri. Information System yang baik dapat mengelola data hasil produksi, nantinya diharapkan dapat membuat informasi yang sesuai dan berguna untuk mendukung pengambilan keputusan bisnis [1]. TI melayani dan menyediakan kemampuan bagi mereka untuk memenuhi kebutuhan pengguna [2]. IS dan teknologi yang dapat mengelola data hasil produksi harus menyampaikan output yang diharapkan. Data yang aman, data yang rahasia, keefektifan \& keefisienan, dan tersedianya data harus mampu di awasi dan di dimonitor dengan benar [3].
PT. Ikido Jorr Sepatu Indo adalah perusahaan yang bergerak di bidang produksi dan pabrik, perusahaan tersebut memproduksi produk berupa, sepatu bayi. PT Ikido Jorr Sepatu Indo menjual produknya di beberapa kota di pulau jawa, salah satunya di Jakarta, Bogor, Semarang, dan Surabaya.

Peneliti menemukan masalah berupa, belum maksimalnya penggunaan teknologi dan informasi membuat pemasukan data menjadi tidak akurat, memperlambat proses bisnis, dan kurang kompetitif di era yang serba modern sehingga pihak perusahaan tertarik untuk menerapkan arsitektur enterprise, sistem informasi merupakan salah satu usaha dalam mengelola data dan informasi yang nantinya dapat dimanfaatkan oleh perusahaan [4], oleh karena itu peneliti akan merancang TOGAF enterprise architecture guna menyelaraskan sistem informasi dan teknologi informasi dengan proses bisnis yang sedang berjalan.

Perancangan arsitektur yang dilakukan peneliti menggunakan framework The Open Group Framework (TOGAF) karena TOGAF menyediakan metode yang sistematis dan peralatan atau tools yang berguna untuk perancangan arsitektur enterprise [5]. TOGAF ADM menyediakan siklus perancangan,yang digunakan merancang, mengembangkan dan menerapkan arsitektur sistem informasi untuk perusahaan [6]. Perancangan TOGAF ini diharapkan dapat membantu perubahan dari proses manual menjadi lebih memanfaatkan sistem informasi dan teknologi secara maksimal [7].

Isu penting yang perlu ditangani pada penelitian ini adalah perancangan EA yang sesuai dengan proses bisnis dan tujuan bisnis, hal ini penting untuk dikaji mengingat EA dapat menjebatani antara teknologi informasi dengan bisnis, agar dapat mengembangkan perusahaan. Aplikasi yang dirancang juga mempercepat proses bisnis yang berlangsung, pemrosesan data dan pengiriman data dapat dilakukan secara realtime, dan website dapat membantu memasarkan produk. 


\section{TINJAUAN PUSTAKA}

\section{A. Architecture Enterprise}

Pengertian arsitektur umum menurut KBBI adalah metode dan gaya rancangan suatu konstruksi bangunan [8], berikut adalah pengertian arsitektur:

- Arsitektur adalah sebuah komponen sistem terdiri dari jaringan perangkat lunak dan keras yang restruktur.

- Rancangan untuk segala struktur yang berbentuk fisik maupun maya.

Arsitektur enterprise merupakan basis informasi strategis, yang digunakan untuk menentukan dan menetapkan visi dan misi, dan menyiapkan teknologi \& informasi yang dibutuhkan untuk mencapai tujuan dari visi dan misi tersebut, arsitektur enterprise ini sendiri menyelaraskan implementasi TI yang sudah diterapkan dengan proses bisnis yang sudah di terapkan di sumber perusahaan tersebut [9]. Arsitektur enterprise adalah sebuah kegiatan manajemen dan teknologi yang diajukan untuk meningkatkan kinerja perusahaan, sesuai dengan strategi, praktik bisnis, informasi, dan sumber daya TI [10].

\section{B. TOGAF ADM}

TOGAF dikembangkan dan di rilis oleh The Open Group's Architecture Framework [11] di tahun 1995, tujuan awal dari TOGAF adalah untuk kepentingan keamanan Amerika Serikat, namun seiring dengan berkembangnya jaman TOGAF digunakan pada bidang lain seperti industri manufaktur, perbankan, dan juga pendidikan [12]. TOGAF menyediakan metode dan alat untuk membangun, merancang, mengimplementasi, dan mengelola arsitektur enterprise [13].

ADM atau Architecture Development Method adalah hal penting pada pengimplementasian TOGAF, dengan diagram lingkarannya (TOGAF Wheel), yang mendeskripsikan beberapa fase dari metode TOGAF ADM dan berikut adalah fase dari TOGAF Wheel [14]:

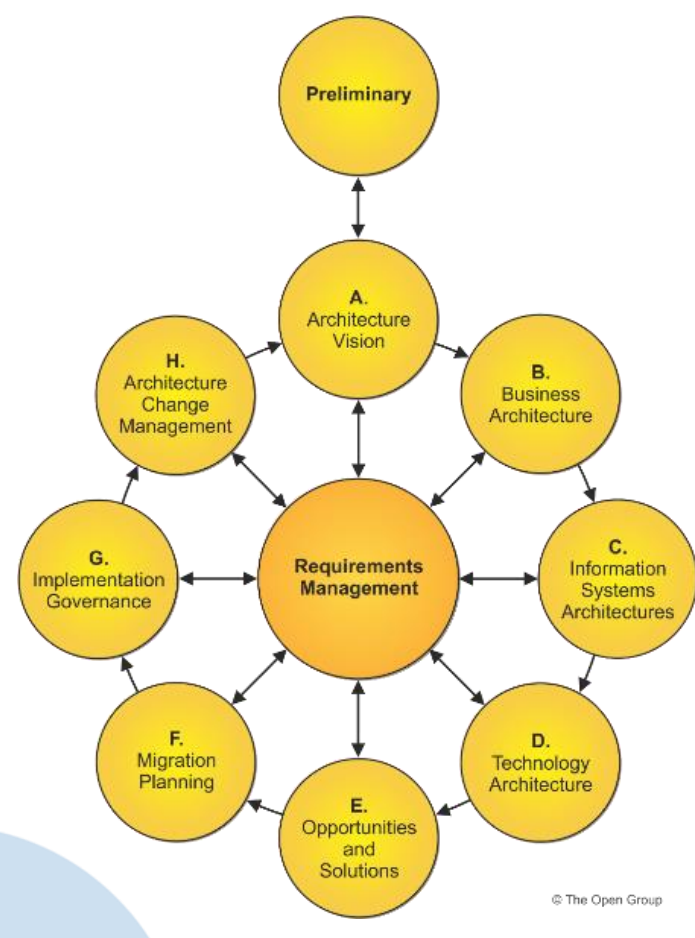

Gambar 1. TOGAF wheel [15]

Tahapan TOGAF terdiri atas [16]:

1. Preliminary Phase (Tahap Pendahuluan), menerangkan aktivitas pendahuluan dan permulaan yang dibutuhkan untuk melengkapi kebutuhan bisnis untuk blueprint organisasi yang baru, termasuk definisi kerangka Arsitektur perusahaan dan mengdefinisikan kembali azas-azas dari setiap anggotanya.

Pada fase ini "individu" yang membangun arsitektur mengidentifikasi $5 \mathrm{~W}+1 \mathrm{H}$ yaitu: "siapa", "apa", "mengapa", "kapan", "dimana", dan "mengapa" dari arsitektur ini sendiri:

- "Apa" adalah scope atau ruang lingkup dari arsitektur bisnis.

- "Siapa" ialah WHO WILL PROVIDE merancang modelnya, siapa personal yang RESPONSIBLE untuk membangun arsitektur tersebut.

- “Bagaimana" adalah bagaimana seorang individu merancang Enterprise Architecture, menetapkan kerangka kerja yang paling cocok dan memilih cara yang tepat yang nantinya akan dipergunakan dalam memenuhi output yang dibutuhkan.

- "Bila mana" adalah kapan perancangan arsitektur dapat diselesaikan. 
- "Mengapa" adalah mengapa arsitektur ini diperlukan, berkaitan dengan tujuan visi misi perusahaan, yaitu bagaimana caranya arsitektur yang dirancang ini dapat memfasilitasi goal dari perusahaan.

- "Dimana" adalah penunjukan lokasi tempat kerja dari perusahaan. Apakah lokasi kantor organisasi berada di dalam ruang atau bangunan, atau memiliki cabang kantor di satu negara atau di sekeliling dunia.

2. Phase A: Architecture Vision (Arsitektur Visi), memberikan penjelasan tahap pertama dari pengembangan arsitektur. Ini meliputi output tentang menata kembali ruang lingkup, mengidentifikasi stakeholders, dan Mengdesain ulang Visi Arsitektur.

3. Phase B: Business Architecture (Arsitektur Bisnis), mempunyai dapat mendetilkan basis arsitektur bisnis, membuat lebih baik lagi dari proyek arsitektur bisnis, mengembangkan target dari arsitektur bisnis yang dibangun dan memberikan penjelasan tentang cara untuk memenuhi keperluan organisasi dalam menggapai goal perusahaan yang ditetapkan.

4. Phase C: Information Systems Architectures (Arsitektur Sistem Informasi), mendeskripsikan pengembangan dan perancangan untuk Arsitektur output berupa untuk proyek arsitektur, termasuk pengembangan Arsitektur Data dan perangkat lunak.

5. Phase D: Technology Architecture (Arsitektur Teknologi), merancang arsitektur teknologi sesuai dengan aplikasi yang terkait dan arsitektur data, termasuk perangkat lunak dan perangkat keras.

6. Phase E: Opportunities \& Solutions (Opsi peluang \& Solusi), melakukan perencanaan implementasi dan identifikasi pengantaran arsitektur yang sudah ditentukan dalam fase sebelumnya. Pada tahap ini akan dilakukan evaluasi model yang telah dibangun untuk arsitektur yang sudah diterapkan.

7. Phase F: Migration Planning (Perencanaan Migrasi), membahas penyusunan serangkaian urutan arsitektur transisi yang terperinci dengan Rencana Implementasi dan Migrasi yang mendukung.

8. Phase G: Implementation Governance (Implementasi Tata Kelola), menyediakan rencana kerja dan mengelola proyek untuk menggapai kesuksesan arsitektur yang dibutuhkan.
9. Phase H: Architecture Change Management (Manajemen Perubahan Arsitektur), tahapan ini bertujuan untuk menjamin arsitektur yang baru sudah menggapai tujuan perusahaan dan juga untuk memutuskan / menyusun proses manajemen peralihan arsitektur untuk arsitektur enterprise yang akan diterapkan.

\section{Metodologi Penelitian}

Tahapan-tahapan riset yang harus dilakukan dan kegiatan-kegiatan di lapangan yang dilakukan dalam riset ini. Tahapan penelitan yang di lakukan pada perancangan ini adalah sebagai berikut [17].

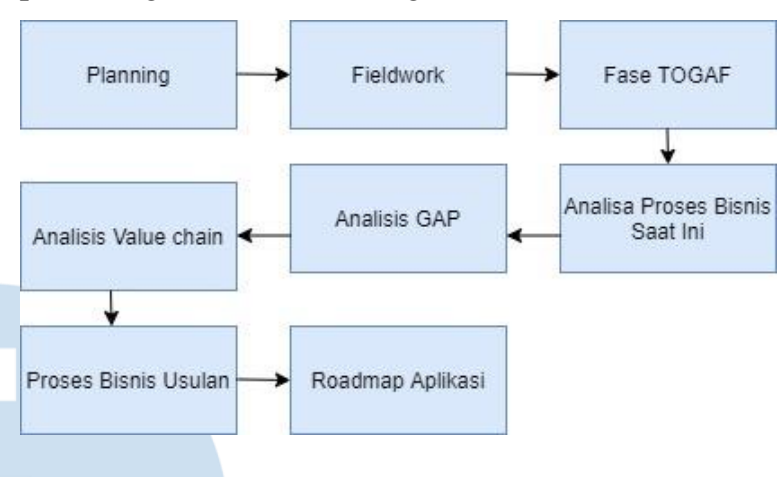

Gambar 2. Metode penelitian [17]

1. Planning (Rencana):

Tahapan awal peneliti akan memastikan Scope proyek yang akan di teliti, yang dilakukan adalah melakukan wawancara dengan orang yang berkepentingan di organisasi yang akan di teliti dengan observasi dan memberikan analisa terhadap vision, mission, target dan goal dari perusahaan.

\section{Field Work (Observasi ke Perusahaan)}

Peneliti melakukan banyak hal untuk memperoleh informasi yang dibutuhkan dengan cara menampung dan mengumpulkan data dari individu yang berwenang terkait objek penelitian dengan menggunakan metode seperti, tanya jawab, dan observasi dan survei langsung ke perusahaan sepatu.

\section{Fase TOGAF:}

Peneliti melakukan perancangan TOGAF dari fase preliminary hingga fase $\mathrm{F}$ migration planning agar dapat menghasilkan enterprise architecture yang diharapkan oleh perusahaan.

\section{Analisa Value Chain:}

Peneliti melakukan analisa value chain untuk mengetahui proses bisnis yang berlangsung guna untuk mendapatkan informasi untuk membuat arsitektur rancangan yang diharapkan. 


\section{Analisa GAP:}

Peneliti menetapkan komponen proses bisnis apa saja yang akan dihilangkan, dipertahankan, diganti dari proses yang berjalan saat ini.

\section{Perancangan Arsitektur Usulan:}

Peneliti akan merancang arsitektur usulan yang dapat membantu proses menyelaraskan proses bisnis yang berjalan dengan sistem informasi dan teknologi.

\section{Roadmap Aplikasi:}

Peneliti akan membuat tabel roadmap untuk menentukan prioritas aplikasi apa saja yang akan dirancang terlebih dahulu.

\section{Reporting (Membuat laporan):}

Bagian akhir dari proses perancangan sudah selesai dilakukan, maka dari hasil yang didapatkan akan digunakan untuk membangun perancangan yang diinginkan, perancangan akan dibuat sesuai dengan fase TOGAF Wheel. Hasil dari perancangan ini adalah berupa Blueprint (cetak biru).

\section{PEMBAHASAN}

\section{A. Fase TOGAF}

- Preliminary Phase (tahap pendahuluan): pada tahap ini bertujuan untuk menentukan kembali apa yang akan dilakukan dalam merancang blue print di industri sepatu ini, dengan menentukan prinsip - prinsip sebagai acuan pengembangan arsitektur dan mengidentifikasi $5 \mathrm{~W}+1 \quad$ dalam perancangan arsitektur.

- Requirement Management: tujuan dari tahap untuk untuk memberikan analisa dan mengendalikan keperluan dari seluruh tahapan yang ada di TOGAF ADM, dengan melakukan analisa sistem berjalan, mengidentifikasi permasalahan yang terdapat di perusahaan, dan membuat solusi sistem informasi untuk permasalahan tersebut.

- Phase A Architecture Vision: pada fase ini bertujuan untuk menciptakan kesamaan dalam pandangan mengenai pentingnya enterprise architecture untuk mencapai tujuan perusahaan, yang dirumuskan dalam bentuk strategi, menguraikan visi - misi perusahaan, menggambarkan struktur organisasi dan tugasnya, mengalisis aktivitas utama dan aktivitas pendukung perusahaan, serta membuat organisasi usulan.

- Phase B Business architecture (Tahap Arsitektur Bisnis): menetapkan tipe kegiatan bisnis yang diharapkan perusahaan dengan membuat pemetaan pelayanan dari bisnis, proses bisnis yang dilakukan, dan kegunaan bisnis, dan blue print bisnis dari perusahaan.

- Phase C Information System Architecture: pada fase ini akan membahas mengenai bagaimana arsitektur sistem informasi dibangun meliputi arsitektur aplikasi dan arsitektur data yang akan digunakan di perusahaan.

- $\quad$ Phase D Technology Architecture: pada fase ini menentukan pemodelan yang dibutuhkan untuk mendukung bisnis perusahaan dan membuat pemodelan konfigurasi jaringan internal, konfigurasi software dan hardware.

- Phase E: Opportunities \& Solutions: pada tahapan ini akan mengevaluasi kans dan solusi dalam contoh/gaya yang telah dirancang dengan menggunakan gap analisis. Peluang adalah menentukan sistem yang dapat dipertahankan dan solusi adalah penambahan sistem baru dan mengganti sistem yang tidak diperlukan.

- Phase F Migration Planning: pada tahapan ini akan dilakukan perencanaan migrasi dari sistem lama ke sistem baru, dengan melakukan penyusunan urutan implementasi aplikasi berdasarkan prioritas, menentukan roadmap aplikasi dan membuat perencanaan target implementasi.

\section{B. Analisis Value Chain}

\section{Aktivitas Utama}

- Inbound Logistic, membeli bahan baku untuk memproduksi dari supplier.

- Operation, dalam proses operasi di PT Ikido Jorr Indo Sepatu, dilakukan setelah pembelian bahan baku, yang nanti bahan baku akan diproduksi di home industry yang berada di Bogor, Ciomas. Pertama adalah proses cutting process di mana pemotongan bahan baku membentuk pola - pola untuk bagian upper sepatu, pemotongan dilakukan dengan mesin cutting. lalu proses selanjutnya adalah stitching di mana pola pola yang sudah cutting di jahit untuk membuat bagian upper sepatu. Selanjutnya adalah proses pembuatan outsole atau bagian terbawah sepatu. Lalu membuat insole atau bagian dalam sepatu. Dan yang terakhir dalam fase produksi adalah assembly atau penyatuan / perakitan bagian - bagian yang sudah diproduksi sebelumnya menjadi model sepatu yang diinginkan. produk yang sudah jadi, masuk ke fase quality control di mana pengecekan apakah sepatu sudah masuk ke dalam kategori layak untuk dijual, dan jika 
produk sudah lulus fase quality control produk akan dikemas.
- Outbound Logistic, produk yang sudah dikemas akan dikirimkan langsung ke pelanggan.

\begin{tabular}{|c|c|c|c|c|}
\hline \multicolumn{5}{|c|}{ Pengadaan } \\
\hline \multicolumn{5}{|c|}{ Keuangan } \\
\hline \multicolumn{5}{|c|}{ Kepegawalan } \\
\hline Inbound Logistic & Operation & Outbound Logistic & Sales \& Marketing & Services \\
\hline $\begin{array}{l}\text { 1. Memastikan terpenuhl } \\
\text { nya bahan baku } \\
\text { 2. Memastikan kualitas } \\
\text { bahan baku }\end{array}$ & $\begin{array}{l}\text { 1. Produks| } \\
\text { 2. Quality Control } \\
\text { 3. Pengemasan }\end{array}$ & $\begin{array}{l}\text { 1. Memastikan pengiriman } \\
\text { produk sampai ke pelanggan } \\
\text { tepat waktu } \\
\text { 2.Memastikan barang yang } \\
\text { dikirim dalam kondisi balk } \\
\text { dan tidak rusak }\end{array}$ & $\begin{array}{l}\text { 1. Memastikan pesanan } \\
\text { pelanggan dicatat dengan } \\
\text { baik dan benar } \\
\text { 2.membangun dan menjaga } \\
\text { relasi balk dengan } \\
\text { pelanggan }\end{array}$ & $\begin{array}{l}\text { Menawarkan produk dengan } \\
\text { harga bersaing, tapi dengan } \\
\text { kualltas yang baik }\end{array}$ \\
\hline
\end{tabular}

Gambar 3. Analisis value chain

- Sales and Marketing, Memastikan semua pesanan dicatat dengan rinci dan detail. PT.Ikido Jorr Indo Sepatu memberikan harga dengan harga yang bersaing, mutu produk yang tinggi dan ketepatan waktu pengiriman barang.

- Service, PT.Ikido Jorr Indo Sepatu memberikan harga yang bersaing, kualitas dan mutu barang yang baik serta produk produk yang ber-sertifikat SNI.

\section{Aktivitas Pendukung}

- Pengadaaan, aktivitas ini merupakan pengadaan bahan baku dari supplier, memastikan perusahaan terus memiliki stok untuk mendukung kelancaran kegiatan produk sepatu, kegiatan ini terdiri dari melakukan record catatan, dan pelaporan data yang di pesan.

- Keuangan, aktivitas yang dilakukan di bidang finance dengan usaha meningkatkan jasa layanan finance di area kegiatan bisnis PT. Ikido Jorr Indo Sepatu, seperti mengelola pengawasan pemasukan, melakukan simpanan, dan pengelolaan finance serta report finance tersebut.

- Ke karyawanan, kegiatan ini terdiri dari halhal yang berkaitan dengan admin dan gaji dari karyawan, menggunakan aplikasi Microsoft office dan excel untuk pembuatan laporannya.

\section{Analisis Kesenjangan (GAP) Arsitektur Bisnis}

Bab Analisa kesenjangan mempunyai tujuan untuk memberikan laporan apa saja yang harus di pertahankan, dilenyapkan, dari proses yang saat ini di PT. Ikido Jorr Indo Sepatu dan untuk memberikan bagian-bagian apa saja yang harus di rubah atau diikutkan dengan item yang baru dari arsitektur yang di-proposed.

Berikut adalah tabel analisis GAP dari perusahaan PT. Ikido Jorr Sepatu Indo, disampaikan pada Gambar 4.

Berdasarkan Gambar 4 analisis GAP ada fungsi proses bisnis yang sedang dijalankan dan proses bisnis yang akan diusulkan peneliti. Peneliti mengusulkan perubahan proses bisnis yang digantikan yaitu penggajian karyawan, terima bahan baku, laporan produk jadi, barang keluar, penjualan, pengelolaan data pegawai, keuangan, dan pengiriman barang. Dan peneliti menambahkan proses bisnis promosi produk dan laporan promosi produk. 


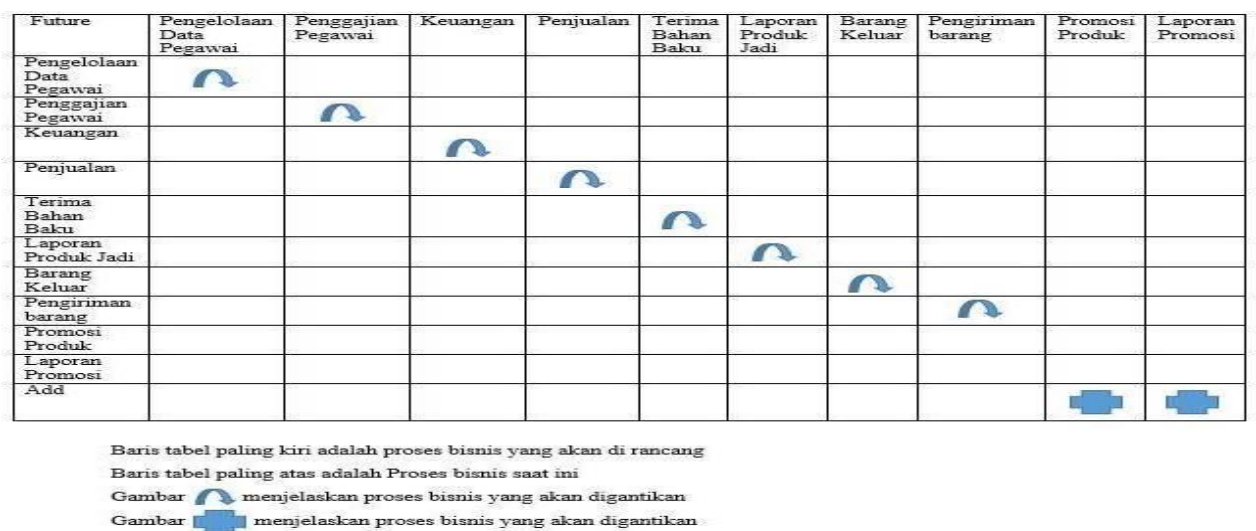

Gambar 4. Analisis GAP

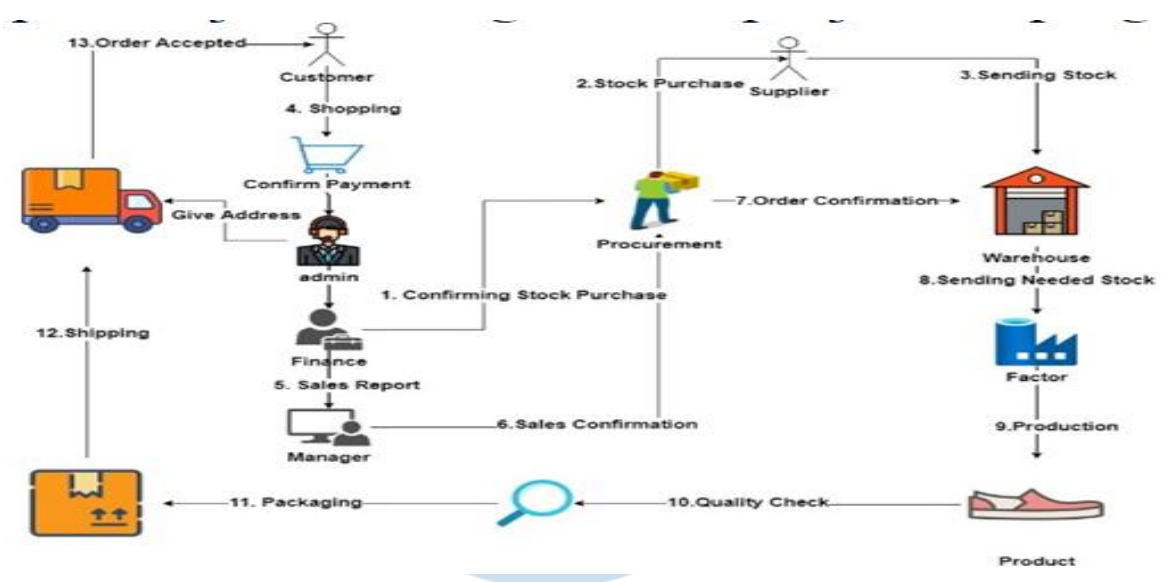

Gambar 5. Proses bisnis saat ini

Berdasarkan Gambar 5 proses bisnis saat ini dapat dilihat bahwa proses bisnis pertama kali dimulai dari bagian keuangan meminta persetujuan pemesanan bahan baku mentah yang dibutuhkan kepada bagian pengadaan, setelah pengadaan mendapatkan persetujuan pembelian dari keuangan, bagian pengadaan akan membeli barang dari supplier, lalu supplier mengirimkan bahan baku mentah ke gudang perusahaan. Setelah konsumen mengkonfirmasi pemesanan dan membayarnya, bagian admin akan mencatat pesanan konsumen dan memberikan info pesanan ke bagian keuangan lalu, bagian keuangan akan melalukan pelaporan kepada manajer mengenai pesanan tersebut. Manajer akan memberikan informasi ke bagian pengadaan, lalu bagian pengadaan akan mengambil barang dari gudang, dan mengirimnya ke pabrik untuk diolah menjadi barang jadi. Selanjutnya barang dari akan diperiksa apa sudah sesuai dengan standar perusahaan, jika sudah barang jadi akan dikemas dan siap untuk dikirim ke alamat konsumen.
D. Analisis Proses Saat Ini

1. Pihak pengadaan mengajukan pembelian barang baku yang dibutuhkan;

2. Manajer menyetujui pembelian barang baku;

3. Keuangan memberikan dana yang diperlukan sesuai dengan pengajuan;

4. Pihak pengadaan menghubungi supplier untuk membeli barang baku;

5. Supplier mengirimkan bahan baku yang dibeli ke gudang;

6. Kustomer membeli produk;

7. Bagian keuangan mengkonfirmasi pembayaran dengan bukti transfer;

8. Admin memberikan laporan pemesanan ke pihak pengadaan;

9. Pihak pengadaan mengkonfirmasi pemesanan; 
10. Bagian pengadaan gudang mengirimkan barang baku yang diperukan untuk produksi;

11. Aktivitas produksi;

12. Quality check untuk setiap produk jadi;

13. Proses pengemasan;

14. Admin memberikan informasi alamat ke pihak transportasi;

15. Proses pengiriman;

16. Produk sampai ke kustomer.

\section{E. Proses Bisnis yang Di-proposed}

Dari Gambar 6, Proses Bisnis yang di proposed oleh peneliti mengusulkan beberapa usulan yaitu:
- Website, konsumen dapat membuat pesanan di sini;

- Aplikasi Pengadaan, memudahkan perusahaan untuk mengelola stok bahan baku, dan melihat jumlah produk jadi;

- Aplikasi Keuangan, perusahaan dapat mengatur keuangan diaplikasi ini;

- Aplikasi Admin, perusahaan dapat mengelola berbagai macam kegiatan admin di aplikasi ini;

- Aplikasi Penjualan, perusahaan dapat mengelola data pesanan yang dipesan di aplikasi ini.

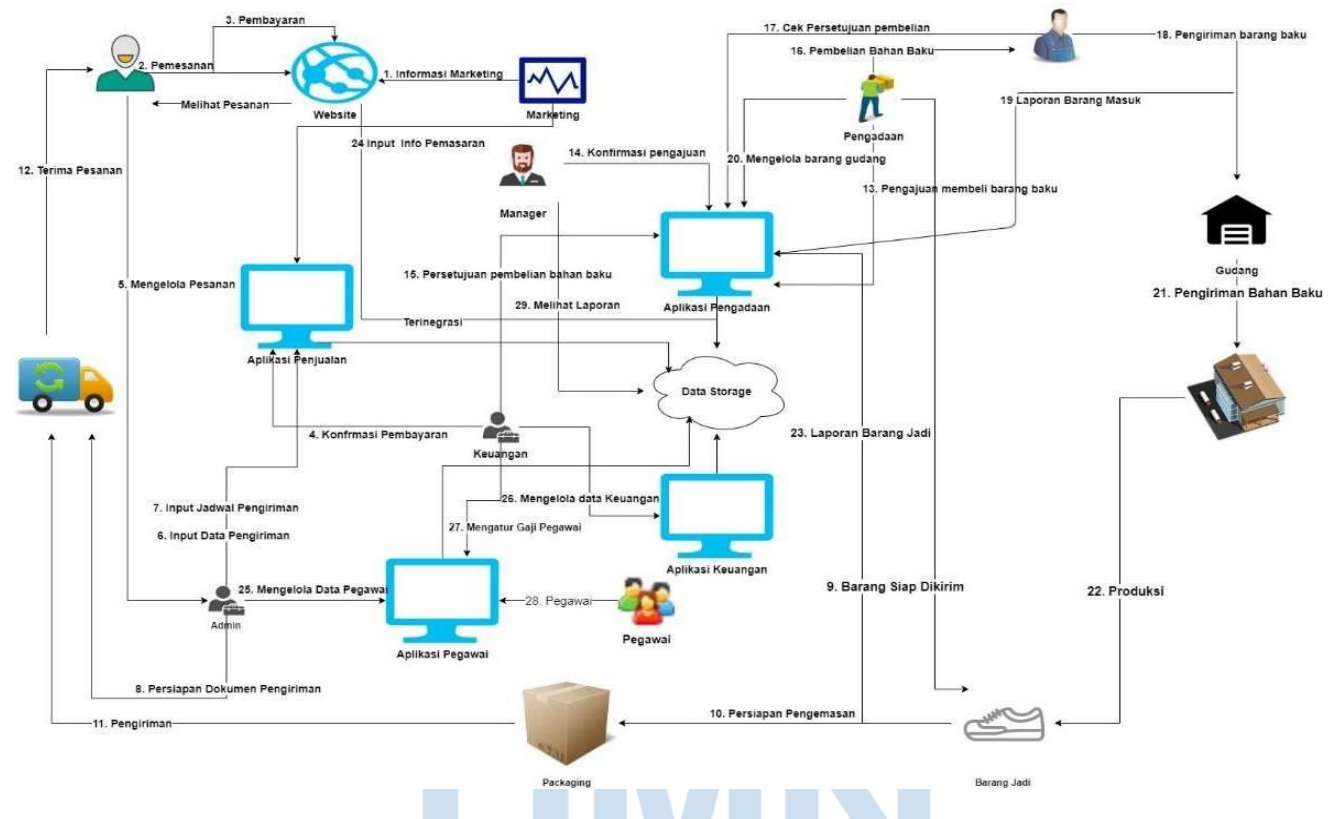

Gambar 6. Proses bisnis yang di-proposed

1. Pertama marketing akan meong - input informasi penjualan ke website PT. Ikido Jorr Indo Sepatu;

2. Konsumen dapat memilih produk yang diinginkan;

3. jika sudah memilih konsumen dapat membayarnya via online;

4. Keuangan akan mengkonfirmasi pembayaran yang dilakukan konsumen di aplikasi penjualan;

5. Admin akan mengelola pesanan apa saja yang dipesan konsumen;

6. lalu admin akan memasukan data pengiriman di aplikasi penjualan;

7. memasukan jadwal pengiriman;
8. dan membuat dokumen yang dibutuhkan untuk pengiriman, memberikannya ke bagian transportasi;

9. Selanjutnya pengadaan akan menyiapkan produk yang dipesan;

10. Produk akan dikemas;

11. dan dikirim sampai diterima oleh konsumen;

12. Pesanan diterima konsumen;

13. Berikutnya adalah pihak pengadaan membuat pengajuan membeli barang baku;

14. Manajer dapat melihat barang apa saja yang dipesan, jika dikonfirmasi oleh manajer;

15. Pihak keuangan dapat memberi dana untuk membeli bahan baku yang diperlukan; 
16. Jika sudah mendapat dana, pengadaan dapat membeli apa yang diperlukan;

17. Supplier mengecek apa yang dipesan oleh pengadaan;

18. Supplier mengirim barang ke gudang;

19. Barang yang sampai di gudang akan di input datanya ke aplikasi pengadaan dan pihak pengadaan dapat mengelola barang masuk;

20. Bagian pengadaan dapat mengelola barang masuk dengan aplikasi pengadaan;

21. Pengiriman bahan baku yang diperlukan untuk stok produksi;

22. Proses produksi;

23. Laporan barang jadi;

24. Marketing dapat info promosi / pemasaran ke website;

25. Bagian kepegawaian dapat mengatur data pegawai dan penggajian di aplikasi pegawai;

26. Bagian keuangan dapat mengatur seluruh aktivitas keuangan di aplikasi keuangan;

27. Manajemen penggajian pegawai;

28. Pegawai dapat melakukan absensi di aplikasi pegawai;

29. Manajer dapat melihat laporan dari setiap aktivitas bisnis.

\section{F. Road Map Aplikasi}

Pada Gambar 7 Road Map Aplikasi, dapat dijelaskan sebagai berikut:

1. Website Perusahaan mendapatkan antrian yang utama karena aplikasi yang dimaksud menjadi perantara untuk menyelaraskan semua perangkat lunak yang ada.

2. Antrian selanjutnya adalah perangkat lunak pengadaan karena software pengadaan akan digunakan untuk mengatur pergudangan perusahaan sehingga pengelolaan data dan informasi persediaan dapat diakses secara cepat dan realtime.

3. Untuk urutan ketiga adalah aplikasi penjualan yang digunakan untuk mengelola pesanan masuk dari pelanggan.

4. Urutan keempat adalah aplikasi keuangan untuk mengelola data keuangan perusahaan.

5. Urutan kelima adalah aplikasi kepegawaian untuk mengelola data pegawai.

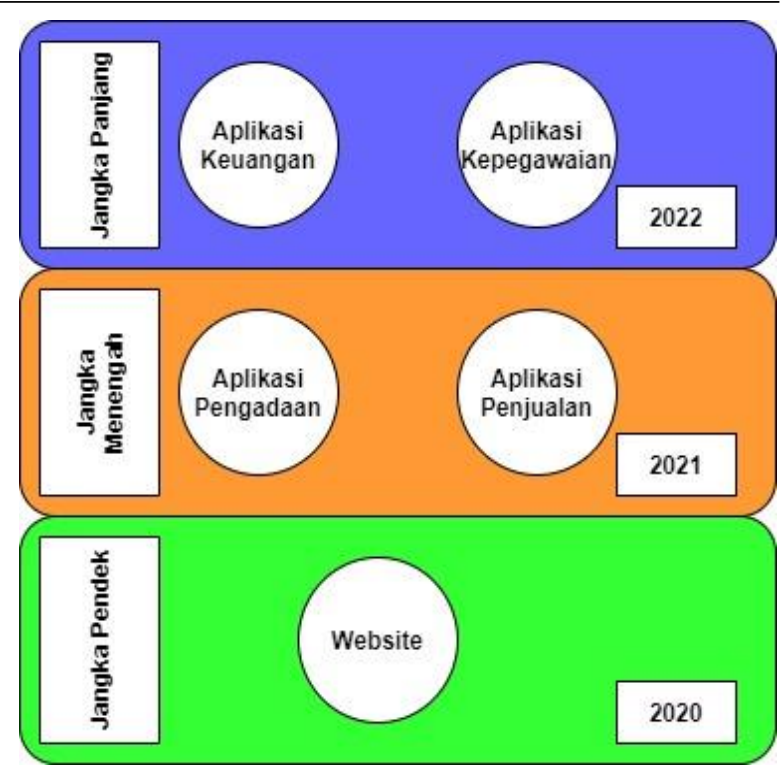

Gambar 7. Road map aplikasi

\section{KESIMPULAN}

Berdasarkan penulisan di atas, peneliti memperoleh beberapa keputusan dari paper ini sebagai berikut:

- Dalam proses bisnis PT. Ikido Jorr Indo Sepatu, belum memaksimalkan penggunaan sistem informasi dan teknologi informasi sehingga penelitian ini bertujuan untuk mendesain arsitektur perusahaan untuk dapat mensinergikan strategi bisnis yang sedang berjalan dan strategi dari IS/IT. Desain arsitektur enterprise yang digunakan adalah kerangka kerja TOGAF yang menghasilkan cetak biru berupa arsitektur bisnis.

- Enterprise arsitektur yang dirancang arsitektur bisnis untuk PT. Ikido Jorr Indo Sepatu diharapkan dapat memudahkan proses pengiriman dan pengelolaan data.

\section{DAFTAR PUSTAKA}

[1] H. Hartono, R. Meylovsky, and J. F. Andry, "Arsitektur Enterprise Pada BMKG Dengan Framework TOGAF ADM," J. Technol. Inf., vol. 6, no. 1, pp. 29-34, 2020.

[2] J. F. Andry, "Conceptual Framework for Successful ITGovernance and BSC for Service Industry," IJSRT (International J. Innov. Res. Technol., vol. 3, no. 5, pp. 1-6, 2018.

[3] S. B. Elshaddai and J. F. Andry, "Audit Sistem Informasi Inventory Menggunakan," Ikraith-Informatika, vol. 2, no. 2, pp. 26-33, 2018.

[4] A. Basir, A. Fadlil, and I. Riadi, "Enterprise Architecture Planning Sistem Informasi Akademik Dengan TOGAF ADM," J-SAKTI (Jurnal Sains Komput. dan Inform., vol. 3, no. 1, p. 1, 2019, doi: 10.30645/j-sakti.v3i1.91.

[5] E. S. Almunadia, T. F. Kusumasari, and I. Santosa, "Perancangan Enterprise Architecture Pada Bidang Agroforestry Menggunakan Metode Togaf 9.1 Adm," J. RESTI (Rekayasa Sist. dan Teknol. Informasi), vol. 3, no. 2, 
pp. 210-215, 2019, doi: 10.29207/resti.v3i2.958.

[6] R. Adrianti and N. Ibrahim, "Penggunaan TOGAF ADM 9.1 Pada Perancangan Enterprise Architecture Fungsi Layanan Beasiswa Universitas Kristen Maranatha," J. Tek. Inform. dan Sist. Inf., vol. 5, no. 1, pp. 14-26, 2019, doi: 10.28932/jutisi.v5i1.1578.

[7] A. Gormantara and A. W. R. Emanuel, "Enterprise Architecture Planning Using TOGAF-ADM at Scoob Telur Company," INTENSIF J. Ilm. Penelit. dan Penerapan Teknol. Sist. Inf., vol. 4, no. 1, pp. 38-50, 2020, doi: 10.29407/intensif.v4i1.13197.

[8] KBBI, "https://kbbi.web.id/arsitektur," 2020.

[9] J.- Leonidas and J. F. Andry, "Perancangan Enterprise Architecture Pada Pt.Gadingputra Samudra Menggunakan Framework Togaf Adm," J. Teknoinfo, vol. 14, no. 2, p. 71, 2020, doi: 10.33365/jti.v14i2.642.

[10] R. Indriani, M. Murahartawaty, and R. Hanafi, “Analisis Dan Perancangan Technology Architecture Menggunakan the Open Group Architecture Framework Architecture Development Method (Togaf Adm) Pada Pt Shafco Multi Trading," J. Rekayasa Sist. Ind., vol. 3, no. 01, p. 1, 2016, doi: $10.25124 /$ jrsi.v3i01.34.

[11] T. O. Group, "https://www.opengroup.org/togaf," 2020.

[12] B. Wicaksono and J. F. Andry, "Perancangan Arsitektur Bisnis Pada Industri Aluminium Foil Menggunakan Togaf," IT J. Res. Dev., vol. 5, no. 1, pp. 98-108, 2020, doi: 10.25299/itjrd.2020.vol5(1).4755.
[13] I. G. Mindrayasa, M. Murahartawaty, and R. Hanafi, "Analisis Dan Perancangan Data Architecture Dan Application Architecture Menggunakan the Open Group Architecture Framework Architecture Development Method (Togaf Adm) Pada Pt Shafco Multi Trading," J. Rekayasa Sist. Ind., vol. 2, no. 03, p. 67, 2015, doi: 10.25124/jrsi.v2i03.67.

[14] A. H. Fikri, W. Purnomo, and W. H. N. Putra, "Perancangan Enterprise Architecture Menggunakan TOGAF ADM pada PT. Hafintech Prima Mandiri,” J. Pengemb. Teknol. Inf. dan Ilmu Komput., vol. 4, no. 7, pp. 2032-2042, 2020.

[15] R. Anggrainingsih, A. Aziz, U. Salamah, and S. Widya Sihwi, "Penyusunan Arsitektur Visi dan Arsitektur Bisnis Sebagai Tahapan Perancangan Arsitektur Enterprise Universitas Sebelas Maret (UNS) Dengan Framework TOGAF," $J$. Teknol. Inf. ITSmart, vol. 2, no. 2, p. 13, 2016, doi: 10.20961/its.v2i2.626.

[16] N. G. Ayu Dasriani and R. Rismayati, "Architecture Enterprise Program Studi S1 Teknik Informatika dengan TOGAF Architecture Development Method (Studi Kasus: STMIK Bumigora Mataram)," MATRIK J. Manajemen, Tek. Inform. dan Rekayasa Komput., vol. 18, no. 1, pp. 97-105, 2018, doi: 10.30812/matrik.v18i1.342.

[17] Suryadi and J. F. Andry, "Perancangan Enterprise Architecture Mengunakan Togaf Architecture Development Method (Studi Kasus: Yakuza Gym Jakarta Barat)," Semin. Nas. TEKNOKA, vol. 2, no. 2502, pp. 129-134, 2017. 